\title{
POSSITION OF LEGAL SERVICE AGREEMENT BETWEEN ADVOCATES AND CLIENTS IN LAW NUMBER 8 OF 1999 ON CONSUMER PROTECTION*
}

\author{
Sa'ida Rusdiana** \\ Department of Civil Law, Faculty of Law Universitas Gadjah Mada \\ Jalan Sosio Justisia No.1 Bulaksumur, Sleman, D.I. Yogyakarta 55281
}

\begin{abstract}
The legal services agreement established between the Advocate and the Client is bent in submission to the provisions set forth in Law Number 8 of 1999 on Consumer Protection. The rights and obligations arising between the Advocate and the Client under legal service agreement shall be protected by Law Number 8 of 1999. In the event of a dispute between the Client and the Advocate, the execution of the legal services agreement may use dispute resolution as stipulated in Law Number 8 of 1999 on Consumer Protection. Advocates can be regarded as business actors as referred to Law Number 8 of 1999 on Consumer Protection, in addition to performing professional duties that adhered to the professional code of ethics and legislation as mandated by Law No. 18 of 2003 on Advocates, an Advocate through a legal services agreement conducting business activities in various economic fields.
\end{abstract}

Keywords: legal services agreement, advocate, consumer protection.

\section{Intisari}

Perjanjian pemberian jasa hukum yang dibuat antara Advokat dan klien tunduk pada ketentuan yang diatur dalam UU No. 8 Tahun 1999 tentang Perlindungan Konsumen. Berkaitan dengan hak dan kewajiban yang timbul antara Advokat dan klien berdasarkan perjanjian pemberian jasa hukum mendapat perlindungan dalam undang-undang tersebut. Apabila terjadi sengketa antara klien dan Advokat dalam pelaksanaan perjanjian pemberian jasa hukum dapat menggunakan payung hukum penyelesaian sengketa sebagaimana diatur dalam UU No. 8 tahun 1999 tentang Perlindungan Konsumen. Advokat dapat dikatakan sebagai pelaku usaha sebagaimana dimaksud dalam UU No. 8 tahun 1999 tentang Perlindungan Konsumen, karena selain menjalankan tugas profesi yang berpegang pada kode etik profesi dan peraturan perundang-undangan sebagaimana diamanatkan oleh UU No. 18 Tahun 2003 tentang Advokat, seorang Advokat melalui perjanjian pemberian jasa hukum menyelenggarakan kegiatan usaha dalam berbagai bidang ekonomi.

Kata Kunci: perjanjian pemberian jasa hukum, advokat, perlindungan konsumen.

\section{Pokok Muatan}

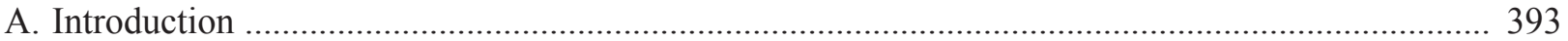

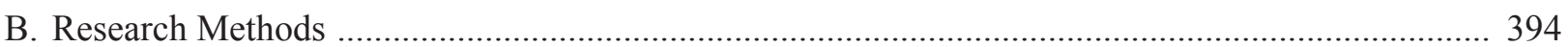

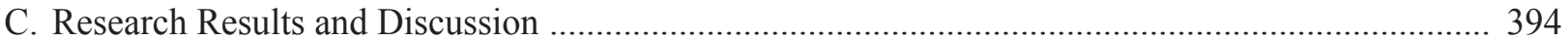

1. Legal Service Agreement between Advocate and Client is Subject to Law No. 8 of 1999 on

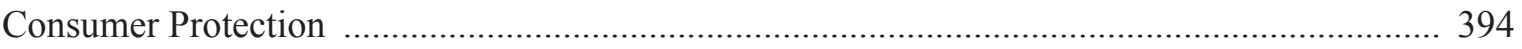

2. Advocates as Business Actors as Meentioned in Law No. 8 of 1999 on Consumer Protection .. 398

D. Conclusion 404 


\section{A. Introduction}

People familiar with some of the terms often used to refer to legal service providers ie Advocates, Lawyers, Legal Advisor and Legal Counsel. In principle these terms refer to a similar profession of Advocates. ${ }^{1}$ Article 1 number 1 of Law No. 18 of 2003 on Advocates defines that: "Advocate is a person who professes to provide legal services, both within and outside the court that fulfills the requirements under the provisions of the Advocate law." Thus it can be said that Advocates are professions that provide legal services.

Today there are many growing corporations that are law firms (Law Firms), where Advocates join and work together in one office and organize themselves into a modern business. Advocates become a profession as well as a livelihood that provides legal services to justice seekers who are then referred to as clients by receiving rewards in the form of honorariaum. In providing legal services to its clients, the law firm establishes an agreement with the client concerned, called a legal service agreement. Like any agreement in general, agreements on the provision of legal services are established and implemented on the basis of agreement between the parties. The agreement contains the rights, obligations and legal liability of each party to the agreement. ${ }^{2}$

The object in the service agreement is a service. Definition of legal services are services provided by Advocates in the form of providing legal consultations, legal assistance, exercising power, representing, accompanying, defending, and performing other legal actions for the client's legal interests. ${ }^{3}$ With regard to the Advocate's authority to assist clients in providing advocacy both inside and outside the courts is based on a power of attorney agreement, usually in the form of a power of attorney. ${ }^{4}$

Advocates have the position of providing legal services to clients who are the recipients of services. There are rights and obligations inherent in the legal relationship between the Advocate and the client. Advocates on the one hand have an obligation to represent the client's affairs or defend the client's interests, but on the other hand is a profession that holds the status of law enforcement. The need for professionals such as Advocates to provide legal services to help communities deal with and solve legal problems faced is also increasing. The increasing awareness of community law and the increasing need for higher legal services make the Advocates' profession now have an important role in society. ${ }^{5}$

In practice, it is not uncommon in the implementation of legal services provisions to have constraints or problems, especially when viewed the position of the parties can be said not balanced in terms of different levels of legal knowledge owned by the parties. Not all clients have legal knowledge. Clients are parties who need legal services to solve legal problems faced. Here as if the bargaining position between clients with Advocates is not balanced. Thus there needs to be a legal protection for clients in their legal relationship with Advocates.

Article 1 number 2 of Law No. 8 of 1999 on Consumer Protection provides the understanding that: "Consumer is every user of goods and/or services available in the community, whether for self-interest, family, other people, or other living beings and not to be traded." consumers in this law then the client who in fact is the recipient of the service can be said as a consumer.

In Law No. 8 of 1999 on Consumer Protection provides arrangements regarding services. Service is any service in the form of work

See Article 32 par. (1) Law Number 18 of 2003 on Advocate.

Anggi Mutiara, "Tinjauan Yuridis Terhadap Perjanjian Pemberian Jasa Hukum Antara Firma Hukum X dengan Kliennya", https://lib. atmajaya.ac.id/default.aspx?tabID $=61 \& \operatorname{src}=k \& i d=40952$, accessed on 5 April 2017.

See Article 1 number 2 Law Number 18 of 2003 on Advocate.

Hadi Herdiansyah, "Perjanjian Jasa Pengacara terhadap Klien”, http://www.hukumonline.com/klinik/detail/cl1834/perjanjian-jasa-pengacaraterhadap-klien-, accessed on 6 May 2017.

Boris Tampubolon, "Pengacara/Advokat dan Konsultan Hukum: Perannya Bagi Masyarakat dan Pelaku Bisnis", https://konsultanhukum.web. id/pengacaraadvokat-dan-konsultan-hukum-perannya-bagi-masyarakat-dan-pelaku-bisnis/, accessed on 5 April 2017. 
or achievement provided for the community to be utilized by consumers. ${ }^{6}$ If it is associated with legal services provided by the Advocate to the client then the services here can be said to be the same as the definition of services as referred to in Law No. 8 of 1999 on Consumer Protection.

Article 1 number 1 of Law No. 8 of 1999 on Consumer Protection provides a definition of consumer protection, which reads: "Consumer protection is any effort that ensures legal certainty to provide protection to consumers." Clients as consumers should also be given legal protection. Article 1 number 3 of Law No. 8 of 1999 on Consumer Protection provides the understanding of business actors, namely, "Business actor is any individual or business entity, whether in the form of a legal entity or not a legal entity established and domiciled or conducting activities within the jurisdiction of the Republic of Indonesia, either alone or jointly through agreements to conduct business activities in various economic fields."

The Advocate may join and cooperate with other Advocates by establishing a law firm. Firm law can be said as a business entity established in a certain region and conduct business activities in the form of legal services. Law firms today are more inclined to profit-oriented business activities. However, it is still a question of whether an Advocate can be regarded as a business actor as referred to in Law No. 8 of 1999 on Consumer Protection. On the other hand, if there is any loss suffered by the client in the implementation of the legal service agreement, does the Advocate also have the legal liability as the business actor as regulated in Article 19 paragraph (1) and paragraph (2) of Law No. 8 of 1999 on Consumer Protection.

Referred to in Article 22 paragraph (1) of Law No.18 Year 2003 on Advocates, it is stated that Advocates are obliged to provide free legal assistance to unfair justice seekers. There is an obligation that is attached to this profession to provide pro bono advocacy to people who can not afford or also known as the term poor. Thus this profession does not necessarily aim to seek profit.

Based on the background of the problems previously described, the following problem formulation can be drawn: First, whether the agreement on legal services between the Advocate and the client is subject to Law No. 8 of 1999 on Consumer Protection?; Secondly, whether Advocates can be regarded as business actors as referred to in Law No. 8 of 1999 on Consumer Protection?

\section{B. Research Methods}

The research method used is normativeempirical by using type of literature research and field. Librarian research yields secondary data, while field research yields primary data. Field research was conducted with interviews to the speakers of Advokat Zahru Arqom and Advokat Arya Maheka. The data collected from literature research and field research are analyzed qualitatively, then presented descriptively to answer the problems studied.

\section{Research Results And Discussion}

1. Legal Service Agreement between Advocate and Client is Subject to Law No. 8 of 1999 on Consumer Protection

\section{a. Research Results}

The authors in this study conducted interviews with several resource persons to explore the agreement providing legal services made between Advocates and clients. One of the resource persons interviewed was Advocates at Maheka \& Co Law Firm. In connection with the service agreement form between client and Advocate at Maheka \& Co. law office divided into 2 (two) that is directly in written form and service agreement online through website in the form of electronic contract. The written and online written services agreement through the website has the same substance which 
regulates the following:
a. The types of legal services to choose from;
b. Terms and conditions of servic- es;
c. Procedure of payment;
d. Terms and Condition.

With regard to the legal protection of the client in the event of loss resulting from the Advocate's action in the exercise of legal services is also provided by Maheka \& Co. law offices. Losses suffered by clients mostly caused by negligence Advocates in the form of misconduct. There are several lawyers for the client to sue the losses it suffered that is through litigation and non litigation. Efforts to solve the often taken is through deliberation of the parties. ${ }^{7}$

Maheka \& Co. Law Offices have faced several complaints from clients. Usually this complaint occurs when the work done by Maheka \& Co is not in accordance with the wishes of the recipient. There are stages for clients who want to complain. The first stage of the client who wishes to file a complaint is to see the concerned Advocate directly. Furthermore, the client can express their intent clearly to the Advocate. The final stage is the provision of solutions desired by consumers through the process of deliberation. Examples of cases of negligence that has been done is in one case of divorce lawsuit with Verdlaard Niet Ontvankelijke Verdlaard or commonly referred to as the decision of NO. The client then complains to the Advocate. Once traced it turns out Advocates forgot to register a photocopy of plaintiff's ID card at the court administration. Solutions provided in the form of compensation by filing a lawsuit again but without the imposition of service fees at all or free. ${ }^{8}$
Some disputes between clients and Advocates are also common. Clients may choose to resolve it in several ways such as reporting to the Honorary Board of PERADI with alleged violations of the Code. Another way that can be taken is to complain to the Indonesian Consumers Foundation (Yayasan Lembaga Konsumen Indonesia) or resolve the dispute through the Consumer Dispute Settlement Agency (Badan Penyelesaian Konsumen Indonesia). According to informants, the violation of consumer rights is a lot happening, but many consumers do not understand the efforts that can be taken to claim these rights. ${ }^{9}$

Other informants also stated that if there are consumers who suffer losses and sue an Advocate then it can be done through some "door" or the consumer basically has a choice of law. However, according to the Advocate Law itself if there is a violation committed by the Advocate then it is reported to the Board of Honor Board. Consumers may report through the Consumer Dispute Settlement Agency, but the decision capacity generated by the Consumer Dispute Settlement Agency itself still raises doubts, because the Consumer Dispute Settlement Agency is only a quasi-judicial institution in which its legal products are only in the form of recommendations and require the willingness of the parties to implement them. Therefore, the decisions issued by the Consumer Dispute Settlement Agency must be re-registered and serve as a corroborative evidence to be asked for execution. The the Consumer Dispute Settlement Agency's rulings have not met the standards set by the courts themselves so in practice the courts sometimes do not want to legitimize them. Quasi justice like this should be minimized so as not to mislead the judicial 
system, so that clients as consumers get legal certainty in filing lawsuits. ${ }^{10}$

Advocate Office of Zahru Arqom \& Co., in the conduct of legal services may base on service agreements between client and Advocate and Law No. 18 of 2003 on Advocates and Code of Ethics Advocates are placed as lex specialists of the Consumer Protection Act. As the doctors profession then the promised is the process is not the result, although sometimes the amount of fees can be associated with the results. The resource persons in this matter pay less attention to the position of the Consumer Protection Law in the process of the implementation of legal services because according to him the behavior, rights and obligations of Advocates have been regulated in Law Number 18 of 2003 regarding Advocate and Advocate Code of Ethics. In this case the reference in running the business of legal services is the Code of Advocate Ethics and the Law of the Program. Default committed by Advocates is more often reported through the Council of Honorary Council of Advocate Organizations, where for Advocates who are proven guilty of violations shall be given sanctions in the form of reprimands, strong warnings, temporary dismissals, and permanent dismissals. However, this does not mean that the implementation of legal services can not be brought to the consumer dispute, because it will basically lead to civil disputes. ${ }^{11}$

The above is also reinforced with information from other sources from the Consumers Institute of Yogyakarta, which states that if consumers are not satisfied with the services provided by the Advocate can report to the Advocate Organization is the Council of Honor Board. ${ }^{12}$

\section{b. Discussion}

The agreement to perform certain services is part of the agreement to undertake a work set forth in Chapter VII A Civil Code. Agreement to perform certain services, namely agreements in which either party wishes on the part of an adversary to do a job in the form of certain services which is a skill, to achieve a goal which he is willing to pay wages while what is done to achieve the same goal once it is up to the opposite party. ${ }^{13}$

Advocates join and work together in an office in the form of a law firm and organize themselves into a modern undertaking. Advocates become a profession as well as a livelihood that provides legal services to justice seekers who are then referred to as clients by receiving rewards in the form of honorariaum. In providing legal services to its clients, the law firm establishes an agreement with the client concerned, called a legal service agreement. As with most agreements, treaties for the provision of legal services are established and implemented on an agreement between the parties. The agreement contains the rights, obligations and legal liability of each party to the agreement. ${ }^{14}$

The object in the service agreement is a service. Definition of legal services are services provided by Advocates in the form of providing legal consultations, legal assistance, exercising power, representing, accompanying, defending, and performing other legal actions for the client's legal interests. ${ }^{15}$ In relation to the Advocate's

Interview with Mr. Zahru Arqom, Advocate of Advocate Office of Zahru Arqom on 13 September 2017.

Interview with Mr. Zahru Arqom, Advocate of Advocate Office of Zahru Arqom on 13 September 2017.

Interview with Mr. Dwi Priyono, Advocate of Advokat pada Yogyakarta Consumers Foundation on 13 September 2017.

Subekti, 1995, Aneka Perjanjian, Citra Aditya Bakti, Bandung, p. 57.

Anggi Mutiara, "Tinjauan Yuridis Terhadap Perjanjian Pemberian Jasa Hukum Antara Firma Hukum X dengan Kliennya”, https://lib. atmajaya.ac.id/default.aspx?tabID $=61 \& s r c=k \& i d=40952$, accessed on 5 April 2017.

See Article 1 number 2 Law Number 18 of 2003 on Advocate. 
authority to assist the client in providing advocacy both inside and outside the court is based on a power of attorney agreement, usually a special power of attorney.

Advocates have the position of providing legal services to clients who are the recipients of services. There are rights and obligations inherent in the legal relationship between the Advocate and the client. Advocates on the one hand have an obligation to represent the client's affairs or defend the client's interests, but on the other hand is a profession that holds the status of law enforcement.

The legal relationship between an Advocate and a client, should use an engaging model of engagement. The lawyer promises to seek the rights of his client not to be harmed while the proceedings are settled by law. Advocates are strictly prohibited from promising a specific outcome. Promising such a result will change the pattern of legal relationships of this profession, which was originally the "inspanningsverbintenis" to "resultaatsverbintenis". ${ }^{16}$

Definition of consumers according to the Indonesian General Dictionary is the user (goods of industrial products, foodstuffs and so on) versus the manufacturer. ${ }^{17}$ Thus it can be said that the consumer is a user of products produced by the manufacturer. Article 1 number 2 of Law No. 8 of 1999 on Consumer Protection provides the understanding that: "Consumer is every user of goods and/or services available in society, whether for selfinterest, family, other people, or other living things and not for trading."

In the economic literature is known the term end consumer and consumer be- tween. The final consumer is the end user or beneficiary of a product, while the intermediate consumer is the consumer who uses a product as part of the production process of another product. The consumer's definition of the Consumer Protection Act is the final consumer..$^{18}$ The definition of a client according to the Great Dictionary of the Indonesian Language is: "a person who obtains legal assistance from an attorney in defense of a case in court; or people who buy something or receive services (such as health, life counseling) on a regular basis." 19

Article 1 number 3 of Law No. 18 of 2003 on the Advocate provides the Client definition is a person, legal entity, or other institution that receives legal services from Advocates. If viewed from the understanding of consumers and clients above then the client can be regarded as a consumer for using or receiving legal services provided by Advocates. If the client does not receive legal services properly or violated his rights then it can use the legal umbrella as stipulated in the Consumer Protection Act.

Law No. 8 of 1999 on Consumer Protection provides a definition of consumer protection, which reads: "Consumer protection is any effort that ensures legal certainty to provide protection to consumers." Thus, in relation to the rights and obligations of clients in legal service delivery agreement taking into account the provisions stipulated in Law No. 8 of 1999 on Consumer Protection. The proceedings in dispute settlement between the client and the Advocate also refer to the provisions in the Consumer Protection Act.

Article 45 paragraph (1) and (2) of

16 Dwi Nurdiyansyah Santosa, 2009, Analisis Yuridis Hak Imunitas dan Malpraktek Advokat serta Implementasinya di Kota Surakarta, Undergraduate Thesis, Faculty of Law Universitas Muhammadiyah Surakarta, p. 102.

W.J.S Poerwadarminta, 1984, Kamus Umum Bahasa Indonesia, Balai Pustaka, Jakarta, p. 769.

See Eludication of Article 1 number 2 Law Number 8 of 1999 on Consumer Protection.

The Indonesian Big Dictionaary-Online (KBBI), "Klien”, ttps://kbbi.web.id/klien, accessed on 7 April 2017. 
Law No. 8 of 1999 on Consumer Protection states:

(1) Any aggrieved consumer may sue a business actor through an agency in charge of resolving disputes between consumers and business actors or through courts residing in the general judicial environment. (2) Consumer dispute resolution can be reached through court or out of court based on the voluntary choice of the parties to the dispute.

Furthermore, Article 47 of Law No. 8 of 1999 on Consumer Protection states that: "A non-court consumer disputes settlement is held to reach agreement on the form and amount of compensation and/or on certain actions to ensure that there will be no return or will not recur losses suffered by consumers."

2. Advocates as Business Actors as Meentioned in Law No. 8 of 1999 on Consumer Protection

\section{a. Research Results}

According to Advokat Arya Maheka, Advocate is a business actor because Advocate runs a service business activity. Advocates' own activities have 2 (two) aspects of running a profession and carrying out economic activities. The aspect of the profession includes an Advocate's idealism in providing social services to the community, while the aspect of economic activity is to provide benefits to the services Advocates provide to clients. The interpretation of business actors in the Consumer Protection Act is expanding. In practice, persons associated with the service business itself include as a business actor. ${ }^{20}$

There are times when the Advocate shall assume responsibility regardless of the cost of a given profession clients, and there are times Advocate benefit by installing certain rates for services rendered. With regard to the obligations of Advocates to provide free legal services, Maheka \& Co. Law Offices. also run proboNo. Clients who receive legal services probono are selected first based on their economic capabilities. ${ }^{21}$

According to resource advocates the title does not make the profession can not take profit. For example, the Foundation is a non profit organization but can receive funds from outsiders, it's just that the benefits are not enjoyed by the owner of the Foundation. Legal Aid Institute is also a non-profit institution only LBH receive funding from clients or government subsidies. $^{22}$

When comparing the profession of Advocates with the Doctor's profession, it can be drawn some differences between the two professions. Basically doctors are different from Advocates because doctors work at a company such as a Hospital or Clinic where doctors become workers. But if the doctor opens his own clinic and at the same time become owner and organize it can be said as a business actor. Advocates themselves have different interdependencies with doctors. Resource persons also added that it is important to understand that service agreements differ from work agreements. ${ }^{23}$

Unlike previous interviewees, Advocate Zahru Arqom sees Advocate's profession through Law Number 18 of 2003 which states Advocates are professions in providing services both inside and outside the court. The client itself can be said to enter into the consumer's understanding as stipulated in the Consumer Protection Act. If interpreted according to the Consumer Protection Act then Advocates are included into business actors. 
Unlike previous speakers, Advocate Zahru Arqom sees Advocate's profession through Law Number 18 of 2003 which states Advocates are professions in providing services both inside and outside the court. The client itself can be said to enter into the consumer's understanding as stipulated in the Consumer Protection Act. If interpreted according to the Consumer Protection Act then Advocates are included into business actors. However, the provisions of the Advocate Law should also be seen as a lex specialist in the eyes of the service industry, but not all services businesses can fall into the category of actors under the Law of Consumer Protection. ${ }^{24}$

Based on the source of the Consumer Dispute Settlement Agency (Badan Penyelesaian Sengketa Konsumen), advocates can be identified as business entities if appointed at certain times such as in the Law of Consumer Protection. However, if the advocate from his profession then issued to the Professional Code of Conduct which is contained in the Law on Advocates. The interviewees have not been able to resolve with a very relevant position that advocates can be used as a pure workforce engaged in the economy as long as more science is needed. ${ }^{25}$

\section{b. Discussion}

In English, advocate means a person who is professionally in court, a person who is a lawyer in the Court. Another translation says that advatritik as a concern. Advocates can be regarded as their work in court as free. ${ }^{26}$ Meanwhile, refers to English Languange Dictionary, advocate is defined as an advocate is lawyer who speaks in favour of someone or defends in court of law. ${ }^{27}$ That is, an Advocate is a lawyer who speaks on behalf of someone or defends them in court. Based on this understanding, it indicates that the scope of the Advocate's work is the work connected to the court and the work outside the court.

Understanding Advocates according to Article 1 point 1 of Law No. 18 of 2003 on Advocates namely: "Advocate is a person who professes to provide legal services, both inside and outside the court that fulfills the requirements under the provisions of the law Advocates." The role of Advocates is to provide legal assistance to clients who have needed good done in in court and out of court.

Article 5 Paragraph (1) of Law Number 18 of 2003 on Advocates states that: "Advocates are law enforcement, free and independent officers guaranteed by law and regulation". In the Explanation of the Law of Advocates explains that what is meant by Article 5 paragraph (1) above is Advocate as one of the tools in the judicial process which has equal position with other law enforcers in carrying out its function to uphold law and justice.

Such a position requires an organization which is the sole container of the Advocate profession as referred to in Article 28 paragraph (1) of the Advocate Law, namely Advocates' organization is the only forum of independent and independent Advocate profession established in accordance with the provisions of this law with a view to improving the quality of the Advocate profession. Therefore, the Advocate organization, PERADI, is essentially a state organ in a broad, independent sense (independent state organ) that also performs state functions. ${ }^{28}$

So after the existence of Article 5 of

\footnotetext{
Interview with Mr. Zahru Arqom, Advocate of Advocate Office of Zahru Arqom on 13 September 2017. Interview with Mrs. Dilla, Staff of Consumer Dispute Settlement Agency accessed on 13 September 2017.

H.A.Sukris Sarmadi, 2009, Advokat Litigasi dan Non Litigasi Pengadilan- Menjadi advokat Indonesia kini, Mandar Maju, Bandung, p. 1.

John Sinclair, "Collins Cobuild English Languange Dictionary”, in Harlen V. Sinaga, 2011, Dasar-Dasar Profesi Advokat, Erlangga, Jakarta, p. 22.

Constitutional Court Verdict Number 014/PUU-IV/2006 concerning Judicial Review on Law Number 18 of 2003 on Advocate.
} 
Law Number 18 of 2003 on Advocates, the position of Advocate is the same as other law enforcement agencies such as judges, prosecutors and police. Advocates are free and independent law enforcement agencies because they are not paid by the state. This is also affirmed in Article 14 of the Advocate Law. With such freedom and independence makes the difference Advocates with other law enforcement agencies.

What can be appointed as an Advocate is a graduate with a higher education background in law and after attending a special education Advocate profession undertaken by the Advocate Organization. Appointment of Advocate is done by Advocate Organization. The Advocate shall comply and adhere to the Code of Conduct of the Advocate and the provisions of the Council of Honor of the Advocate Organization..$^{29}$

Some of the roles undertaken by the Advocate for the role of the Advocate are well realized, providing legal services, providing legal advice, defending client interests, and representing clients in court. ${ }^{30}$ According Ropaun Rambe, Advocate is not just a profession to earn a living, but also must fight for idealism and morality in which there is value of truth and justice. ${ }^{31}$

Advocates are required to maintain good relationships with their clients, the work of legal counsel is the work of trust, which is a good relationship, among others: ${ }^{32}$

a. the legal counsel in taking care of the case prioritizes the client's interests rather than his or her personal interests;

b. legal counsel in civil cases should prioritize peaceful settlement; c. the legal advisor is not allowed to provide information that may mislead his client concerning the matter he is administering;

d. legal advisors are strictly prohibited to guarantee clients against their cases will be won;

e. legal advisors are prohibited to set conditions that limit the freedom of clients to entrust their interests to other legal counsel;

f. the legal counsel shall determine the amount of honor within reasonable limits in view of the client's capacity;

g. legal advisors are prohibited from burdening clients with unnecessary costs;

h. a legal counsel may use the retention right to the client provided that it does not harm the interests of the client that can be remedied.

i. the legal counsel must always hold the secrets of office on matters that are notified to him by the client in confidence and shall keep the secret.

Article 6 of the Law on Advocates, provides for sanctions for Advocates who do violations. Advocates may be subject to action on the grounds of:

a. ignoring or neglecting the interests of his clients;

b. behave in a way that dislikes his opponent or his colleagues;

c. acting, acting, speaking, or issuing disrespectful statements to the law, the rules of distribution, or the court;

d. doing things related to duty, honor, or dignity and dignity of his profession;

e. committing a violation of disgraceful rules and/or acts;

29 See Article 26 par. (2) Law Number 18 of 2003 on Advocate.

Didi Kusnadi, 2012, Bantuan Hukum dalam Islam: Profesi Kepengacaraan dalam Islam dan Praktiknya di Lingkungan pengadilan, Putaka Setia, Bandung, pp. 240-242.

Ropaun Rampe, 2001, Teknik Praktek Advokat, Gramedia Widiasarana Indonesia, Jakarta, p. 33.

2 Martiman Prodjohamidjojo, 1982, Penasehat Hukum dan Bantuan Hukum, Ghalia Indonesia, Jakarta, p. 18. 
f. support for advocacy and/or professional code of ethics Advocates.

In relation to Advocate whether it can be said as a business actor needs to be reviewed based on the definition of business actors as regulated in Law No. 8 of 1999 on Consumer Protection. In Article 1 number 3 of Law No. 8 of 1999 on Consumer Protection provides the understanding of business actors, namely:

Business actor is any individual or business entity, whether in the form of a legal entity or non-legal entity established and domiciled or conducting activities within the jurisdiction of the Republic of Indonesia, either alone or jointly through agreements to conduct business activities in various economic fields.

Based on the results of research known that Advocates meet the elements of business actors as regulated in Law No. 8 of 1999 on Consumer Protection. Advocates may provide legal services individually or under the corporate entity in the form of a Firm. Understanding the Firm under Article 16 of the Commercial Code, is any union established to run a company under a common name. As a business actor, an Advocate both alone and jointly through legal services providing agreements with clients conducting business activities in various economic fields.

Article 1 point 5 of Law No. 13 of 2003 on Manpower provides the definition of Entrepreneur as follow:

a. an individual, a partnership, or a legal entity operating an enterprise of its own;

b. an individual, partnership or legal entity that independently runs a company not his own; c. individuals, partnerships or legal entities residing in Indonesia representing companies as referred to in letter $\mathrm{a}$ and $\mathrm{b}$ domiciled outside the territory of Indonesia.

In principle, the entrepreneur is the one who runs the company either own or not. As an employer, an entrepreneur is an entrepreneur in a working relationship with a worker or a worker, so it can be concluded that the employer is the person who employs the person for himself by providing wages in accordance with the agreement agreed by both parties. ${ }^{33}$

Article 1 point (1) of Law No. 8 of 1997 on Company Documents provides the definition of the company, namely:

The Company is any form of business which carries on regular and continuous activities for the purpose of obtaining profit and or profits, whether organized by individuals or business entities in the form of legal entities or non-legal entities established and domiciled within the territory of the Republic of Indonesia.

The company's actions according to Polak, are pre-planned acts of profit-loss and everything recorded in the book. Here the deeds of the company have two elements that are planned first about the profit-loss and all that is recorded in the book. The last element complies with the provisions of the law that every entrepreneur is obliged to do the bookkeeping. So the company's actions are broader than commercial deeds because the company does not include commercial deeds, doctors lawyers, notaries, bailiffs, accountants, masons, tailors and all charter companies. $^{34}$

Article 1 point (2) of Law No. 8 of 1997 on Company Documents provides the

33 H.M.N. Purwosutjipto, 2007, Pengertian Pokok Hukum Dagang Indonesia: Pengetahuan Dasar Hukum Dagang, Djambatan, Jakarta, p. 17. Abdulkadir Muhammad, 2000, Hukum Perusahaan Indonesia, Citra Aditya Bakti, Bandung., p. 22. 
definition of corporate documents, namely:

Company documents are data, records, and or information made or received by the company in the course of the execution of its activities, whether written on paper or other means or recorded in any form that can be seen, read or heard.

In Article 2 of Law No. 8 of 1997 on Company Documents mentioned that the company documents consist of financial documents and other documents. Furthermore, Article 6 states that bookkeeping consists of scriptures used as bookkeeping basis that affect the change of wealth, debt, and capital. Each company shall make a record consisting of an annual balance sheet, annual profit and loss account, account, daily transaction journal, or any posts containing information about rights and obligations as well as other matters relating to the business activities of a company. according to company needs. ${ }^{35}$ Thus it can be said that every company is obliged to do bookkeeping.

The definition of work is broader than the company's understanding because the element of profit does not become absolute anymore. Action planning does exist but the criterion is not profit-loss but turns to "service to society". The doctor's job at the General Hospital will then show that how much the sick must pay is taken care of by another official who has nothing to do with the doctor. However, if the physician conducts home practice in the afternoon, then the doctor plans his actions on a profit-loss basis and the act is written in the book. This doctor organizes bookkeeping. Here doctors at the General Hospital do a "job", whereas doctors who practice in their own home do "company". ${ }^{36}$

Regarding the position of doctors, lawyers, notaries, and bailiffs, the Dutch East Indies government planner "Wetboek van Koophandel" argues that they do not run the company because they perform their duties on the basis of their personal qualities. They do not run the company but do the work. Polak considered the opinion of the Dutch Government at that time about the position of doctors, lawyers, notaries, and bailiffs, because the masons, carpenters, tailors, and people whose work was based on their personal qualities, they were always seen as running the company. According to Polak, doctors and so it runs the company if they can carry out their work taking into account the estimated profit and loss in bookkeeping. ${ }^{37}$

Understanding of economic activity itself is an activity undertaken by humans to get certain goods or services in accordance with their needs. Economic activity, can also be said as an activity to achieve prosperity in his life. In addition, economic activity can also be interpreted as a way to obtain or achieve goals, in this case goods and services. Thus, it can be said that economic activity aims for the prosperity of individual lives. ${ }^{38}$

The Advocates' profession as law enforcers does not obtain state salary facilities. This is different from other law enforcement professions such as prosecutors, judges and police. In order to meet his needs and survival, an Advocate must conduct his or her own activities. Advocate undertakes a certain business to obtain an item, in this case in the form of payment of a sum of money

\footnotetext{
See Article 5 jo. Article 8 Law Number 8 of 1997 on Company Documents. Abdulkadir Muhammad, Op.cit., p. 23.

H.M.N. Purwosutjipto, Op.cit., p. 16.

Anonymous, "Pengertian Kegiatan Ekonomi: Definisi dan Jenis", https://pengertiandefinisi.com/pengertian-kegiatan-ekonomi-definisi-danjenis/, accessed on 5 September 2017.
} 
as a form of service reward provided by the client. Thus it can be said that Advocates in this case run economic activities.

In relation to the position of the Advocate as a business actor owns the rights and obligations set forth in the Consumer Protection Act. In Article 6 of Law No. 8 of 1999 on Consumer Protection regulates the rights of business actors are:

a. the right to receive payment in accordance with the agreement on the conditions and exchange value of goods and/or services traded;

b. the right to legal protection from misconducted consumer acts;

c. the right to self-defense should be appropriate in the settlement of consumer disputes law;

d. the right to the rehabilitation of a good name if it is legally proven that the consumer's loss is not attributable to the goods and/or services being traded;

e. rights set forth in the provisions of other laws and regulations.

Furthermore, Article 7 of Law No. 8 of 1999 on Consumer Protection is also regulated on the obligations of business actors are:

a. having good faith in doing business;

b. provide true, clear and honest information about the condition and guarantee of goods and/or services and provide explanations of use, repair and maintenance;

c. treat or serve consumers properly and honestly and non-discriminatively;

d. guarantee the quality of goods and/or services produced and/or traded under the provisions of the applicable quality standards of goods and/or services;

e. provide an opportunity for consumers to test, and/or try certain goods and/or services and provide guarantees and/ or warranties on manufactured and/or traded goods;

f. compensate, indemnify and/ or reimburse for losses arising from the use, use and utilization of traded goods and/or services;

g. compensate, indemnify and/ or reimburse if the goods and/ or services received or utilized are not in accordance with the agreement.

Article 14 of the Law on Advocates states that: "Advocates are free to issue opinions or statements in the defense of cases which are their responsibility in the court by sticking to the professional code of ethics and laws and regulations." From the article can be seen the existence of a code of ethics a profession that becomes a guide for Advocates in providing legal services to clients. Thus, in addition to performing the obligations as stipulated in the agreement providing legal services, must also apply the code of ethics in its role as a profession. It is also affirmed in Article 15 of the Law on Advocates stating that: "Advocates are free in carrying out their professional duties to defend the case under their responsibility by sticking to professional codes of ethics and legislation."

Furthermore, Article 16 of the Law on Advocates states that: "Advocates can not be prosecuted either civil or criminal in performing their professional duties with good faith for the interest of Client's defense in court." When referring to this article, an Advocate performing his professional duties with good intentions given protection in the form of free from civil or criminal prosecution. On the other hand if the Advocate in carrying out his professional duties do negligence then still can be prosecuted in civil and criminal. This is of course the same with the concept of Advocate as a business actor, that is, when a negligence is detrimental to the client in the execution of the agreement providing legal services can be prosecuted on the basis of 
default.

Regarding the position of doctors, lawyers, notaries, and bailiffs, the Dutch East Indies government planner "Wetboek van Koophandel" argues that they do not run the company because they perform their duties on the basis of their personal qualities. They do not run the company but do the work. Polak considered the opinion of the Dutch Government at that time about the position of doctors, lawyers, notaries, and bailiffs, because the masons, carpenters, tailors, and people whose work was based on their personal qualities, they were always seen as running the company. According to Polak, doctors and so it runs the company if they can carry out their work taking into account the estimated profit and loss in bookkeeping. ${ }^{39}$

A government doctor performing his duties at a government hospital, the doctor does not run the company but does the work, because he does not take into account the profit and loss and does not disassemble it in his books. However, if the same doctor opens the practice in his own home, he runs the company because he performs his duties by calculating the profit and loss and recording it all in his books. ${ }^{40}$ Thus a lawyer who is stunned in a law firm, can be likened to a doctor because it is considered to run a company that is both doing bookkeeping and taking into account profit and loss.

\section{Conclusion}

Legal service delivery agreements made between Advocates and clients are subject to the provisions set forth in Law No. 8 of 1999 on Consumer Protection. With respect to the rights and obligations arising between the Advocate and the client under a legal service delivery agreement shall be protected by the law. In the event of a dispute between the client and the Advocate in the execution of the agreement providing legal services may use the legal umbrella of the settlement of a dispute as stipulated in Law No. 8 of 1999 on Consumer Protection.

Status of Law No. Law No. 18 of 2003 on Advocates and Advocates Code of Ethics is a legal basis and a code of conduct in the conduct of advocate profession, but the legal service agreement between advocates and their clients is legal relationship born because the agreement is identical with the legal relationship between business actors and consumers.

Advocates can be regarded as business actors as referred to in Law No. 8 of 1999 on Consumer Protection, because in addition to performing professional duties that adhered to the professional code of ethics and legislation as mandated by Law No. 18 of 2003 on Advocates, an Advocate through a legal service agreement conducting business activities in various economic fields. Advocates in conducting business activities in the economic field aims to seek profits by providing legal services to clients. If seen from the legal relationship that emerged between Advocates and clients can be said the same as the legal relationship between business actors and consumers as regulated in Law No. 8 of 1999 on Consumer Protection.

\section{REFERENCES}

\section{A. Books}

Kusnadi, Didi, 2012, Bantuan Hukum dalam Islam: Profesi Kepengacaraan dalam Islam dan Praktiknya di Lingkungan pengadilan,
Putaka Setia, Bandung.

Poerwadarminta, W.J.S, 1984, Kamus Umum Bahasa Indonesia, Balai Pustaka, Jakarta.

Prodjohamidjojo, Martiman, 1982, Penasehat 
Hukum dan Bantuan Hukum, Ghalia Indonesia, Jakarta.

Rampe, Rampau, 2001, Teknik Praktek Advokat, Gramedia Widiasarana Indonesia, Jakarta.

Sarmadi, H.A.Sukris, 2009, Advokat Litigasi dan Non Litigasi Pengadilan- Menjadi Advokat Indonesia Kini, Mandar Maju, Bandung.

Subekti, 1995, Aneka Perjanjian, Citra Aditya Bakti, Bandung.

\section{B. Research}

Santosa, Dwi Nurdiyansyah, 2009, Analisis Yuridis Hak Imunitas dan Malpraktek Advokat, serta Implementasinya di Kota Surakarta, Undergraduate Thesis, Faculty of Law Universitas Muhammadiyah Surakarta.

\section{Anthology}

Sinclair, John, "Collins Cobuild English Languange Dictionary" in Harlen V. Sinaga, 2011, DasarDasar Profesi Advokat, Erlangga, Jakarta.

\section{Internet Articles}

Anggi Mutiara, "Tinjauan Yuridis Terhadap Perjanjian Pemberian Jasa Hukum Antara Firma Hukum X Dengan Kliennya", https://lib.atmajaya.ac.id/default. aspx? tabID=61\&src $=k \& i d=40952$, accessed on 5 April 2017.

Boris Tampubolon, "Pengacara/Advokat dan Konsultan Hukum: Perannya Bagi Masyarakat dan Pelaku Bisnis", https:// konsultanhukum.web.id/pengacaraadvokatdan-konsultan-hukum-perannya-bagimasyarakat-dan-pelaku-bisnis/, accessed on 5 April 2017.

The Indonesian Big Dictionaary-Online (KBBI), “Klien”, ttps://kbbi.web.id/klien, accessed on
7 April 2017.

Anonymous, "Pengertian Kegiatan Ekonomi: Definisi dan Jenis", https://pengertiandefinisi. com/pengertian-kegiatan-ekonomi-definisidan-jenis/, accessed on 5 September 2017.

Herdiansyah, Hadi, "Perjanjian Jasa Pengacara terhadap Klien", http://www.hukumonline. com/klinik/detail/cl1834/perjanjian-jasapengacara-terhadap-klien-, accessed on 6 May 2017.

\section{E. Regulations}

Indonesian Civil Code.

Law Number 8 of 1997 on Company Documents (State Gazette of the Republic of Indonesia Year 1997 Number 18, Supplement to State Gazette of the Republic of Indonesia Number 3674).

Law Number 8 of 1999 on Consumer Protection (State Gazette of the Republic of Indonesia Year 1999 Number 42, Supplement to State Gazette of the Republic of Indonesia Number 3821).

Law Number 13 of 2003 on Manpower (State Gazette of the Republic of Indonesia Year 2003 Number 39, Supplement to State Gazette of the Republic of Indonesia Number 4279).

Law Number 18 of 2003 on Advocate (State Gazette of the Republic of Indonesia Year 2003 Number 49, Supplement to State Gazette of the Republic of Indonesia Number 4288).

\section{F. Court Verdict}

Constitutional Court Verdict Number 014/PUUIV/2006 concerning Judicial Review on Law Number 18 of 2003 on Advocate. 